\title{
TOURISM INDUSTRY IMPACTS ON SPATIAL INEQUALITY IN THE DEAD SEA REGION
}

\author{
Raed Al Tal' ${ }^{*}$, Tala Mukheimer', Rawan Theodory' ${ }^{1}$, Zaid Zwayyed', Nadia Almehdawi', \\ Dina Al Abdallat', Feli Saticilef ${ }^{2}$
}

${ }^{1}$ German Jordanian University, School of Architecture and Built Environment, Department of Architecture and Interior Architecture, P.O. Box 35247, 11180, Amman, JORDAN

${ }^{2}$ Hochschule für Wirtschaft und Umwelt, Schelmenwasen 4, 72622 Nürtingen, Germany

*Corresponding author: Raedaltal@Yahoo.com

Received: March 13

https://DOl-10.24057/2071-9388-2020-216

\begin{abstract}
This research examines the impact of the tourism industry on spatial inequality in the Dead Sea region in terms of income, employment and changes in urban forms. The research assumes that this inequality results from the Dead Sea Development Zone (DSDZ) creation and focuses on the local level of urban analysis with the case study of a small Jordanian village Sweimeh, Quantitative data is used in this study for exploring these changes, uncovering persistent and obvious patterns of land use and exhibiting perspectives for the landscape, while satellite images offer extensive advantages over verified maps. The qualitative analysis combines field observations, a structured questionnaire survey with 270 randomly selected households and semi-structured interviews with 30 purposively selected participants. The results of the research showed that the DSDZ creates spatial inequality between the hotel touristic district and the village due to the high level of place-based development differences associated with urban characteristics, such as infrastructure and services provision. The results revealed that there has been a notable increase in population and area of Sweimeh as well as the locals' income. The population doubled from 2054 in 1994 to 4448 in 2019, the area has increased from $0.15 \mathrm{~km}^{2}$ to $4.40 \mathrm{~km}^{2}$, and the share of jobs in the tourism sector and businesses in the village jumped from $10 \%$ to $50 \%$ in the same period. This study is important since urbanization and spatial management programs received little attention in the DSDZ development agendas. At the academic level, the findings of this research help to establish an assessment tool for testing the socio-economic impact of tourism development on disadvantaged local communities.
\end{abstract}

KEYWORDS: Dead Sea; Jordan; Tourism industry; Spatial planning; Spatial inequality; Urban forms; Local communities

CITATION: Raed Al Tal, Tala Mukheimer, Rawan Theodory, Zaid Zwayyed, Nadia Almehdawi, Dina Al Abdallat, Feli Saticilef (2021). Tourism Industry Impacts On Spatial Inequality In The Dead Sea Region. Geography, Environment, Sustainability, Vol. 14, No 3, p. 54-62 https://DOl-10.24057/2071-9388-2020-216

ACKNOWLEDGMENTS: Thanks for German Jordanian University and the municipality of Swiemeh for data and logistics help during the research.

Conflict of interests: The authors reported no potential conflict of interest.

\section{INTRODUCTION}

The Dead Sea (DS) is a lagoon located between Jordan, Israel, and the West Bank Authority (Fig. 1). It attracts thousands of local and international tourists and is one of the main Jordanian tourist destinations. Major attractions of the DS include its mineral-rich, reputedly therapeutic hypersaline waters, the year-round warm climate, and historical and cultural heritage. To serve these attractions there are thousands of hotel rooms around the DS on the Jordanian and Israeli coasts, with thousands more proposed after the Treaty of Peace (1994) between Jordan and Israel, which had a positive impact on the tourism industry of the Dead Sea Region (Friends of the Earth Middle East [FoEME], 1998). In July 1994, the first public meeting of Israeli and Jordanian leaders was held at the Jordanian Dead Sea Spa Hotel. In 2009 the Dead Sea Development Zone (DSDZ) was created to facilitate a safe touristic hub between Jordan, Israel, and the Palestinian Authority.
The tourism industry continued to develop rapidly from the late 1990s (El-Naser 2020). Despite notorious intermittent conflicts, the overall number of tourists in Israel (not including day excursionists) increased by 27\%, from 2.2 million in 1995 to 2.8 million in 2015. In the same period, the number of tourists in Jordan increased by $370 \%$ and reached 5.3 million (Wendt 2016). Israel welcomed over 4.55 million tourists in 2019,48 \% of whom visited the DS area. In the same year, the number of tourists in Jordan was 4.2 million, which is less than previous years.

In addition to the Treaty of Peace, a number of factors helped to accelerate the urban development and tourism industry of the Jordanian DS shore. On one hand, the Israeli plans to develop up to 5,000 new hotel rooms along the northern shore were halted in part due to fear of sinkhole formation (FoEME 1998). On the other, the Palestinian Authority was deprived of normative rights and control of its DS shoreline. Palestinian tourism is restricted since Israel 


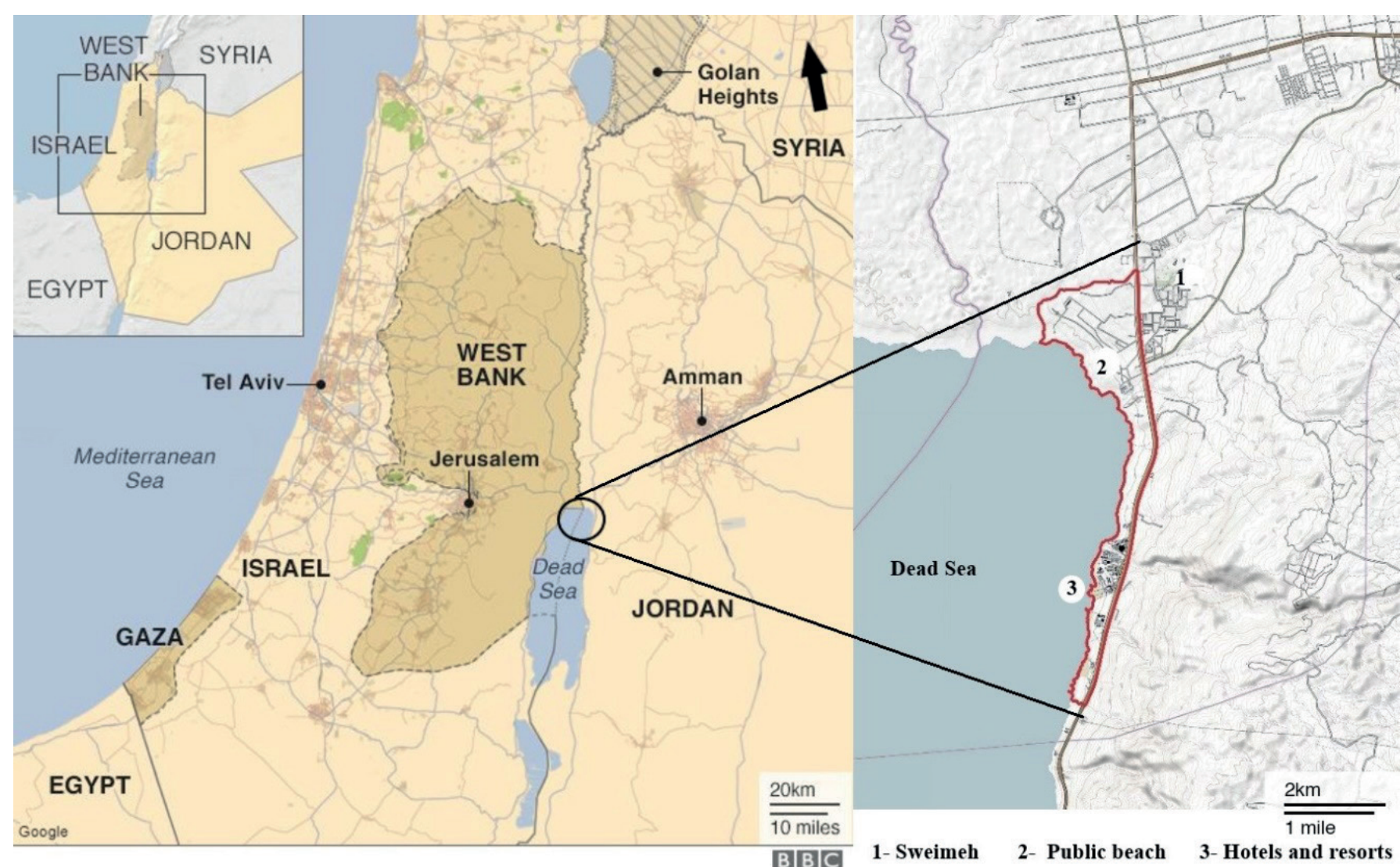

Fig. 1. Three states bordering the north Dead Sea shore and the study area

Source: Google (2021) (left), Alfuqaha et al. (2020) (right)

took control of most tourist sites on the northern shore of the DS, depriving the Palestinians of direct access to it. The western shore of the DS is about $54 \mathrm{~km}$, of which $18 \mathrm{~km}$ are occupied by Israel, while the remaining $36 \mathrm{~km}$ are located within the West Bank (El-Naser 2020) (Fig. 1).

Israel controls tourist access to Jericho, which negatively affects the tourism industry in the city (B'Tselem 2011). Also, Israeli plans for developing infrastructure, such as transportation roads and bridges, are limited due to the geological and rough topographical formation of the sea area, which is prone to collapse and leads to the high costs of construction and maintenance. As a consequence of these challenges, residential development in the area is minimal (Becker and Katz 2006).

Development zones (DZs) provide many benefits, including the attraction of foreign investments, creation of employment opportunities, and distribution of development gains, which eventually leads to the improvement of local living conditions and supports local and national socio-economic development (te Velde 2001). Jordan, as a developing country in the Middle East and North Africa (MENA) region, has adopted a DZ policy since 2008 to encourage economic development and liberalization. By 2014 the government had established a DZ in each of Jordan's twelve governorates in an attempt to develop regional economic production (JFDZ Group 2016). This economic policy was a part of a larger development program known as the Decentralization and Local Development Support Program (DLDSP), sponsored by the European Union, and executed by the United Nation Development Program (UNDP) (Erdmann et al. 2016; USAID 2016). (Fig. 2) shows the spatial distribution of the development zones in Jordan, including the DSDZ within the Balqa governorate (number 6).

Despite the Jordanian governmental efforts to achieve economic growth using the DZ model, the geopolitical location of Jordan plays a fundamental role in its economic development policies. For example, the Jordan Valley Region was a site of conflict and wars until the signing of the Jordanian Israeli Peace Treaty in 1994. In addition, political instability in neighboring countries after the Arab Spring in 2011 discouraged many foreign investors from investing in Jordan. This research argues that despite this economic instability, the DSDZ has achieved its touristic development goals on the national level, but failed to materialize benefits at the level of local communities, which are the focal point of this research.

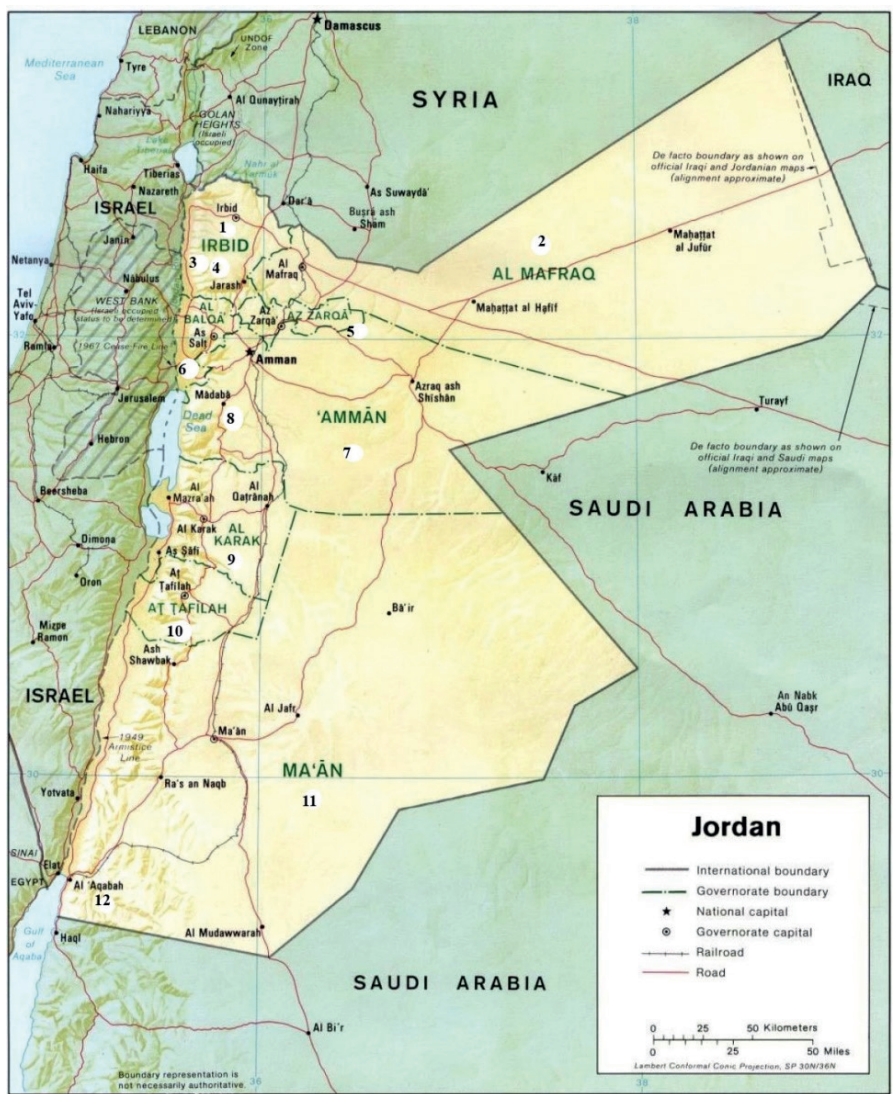

Fig. 2. Jordan's tourism development zones (numbers $3 \& 6$ ) Source: Google (2021) 
Jordan has always considered tourism development to be a key national economic sector, due to the country's abundant natural and historical tourism resources. The government took serious decisions to promote tourism through the DSDZ as a national model (Jordan Investment Commission 2014). This research aims to study the impact of the DSDZ on socioeconomic and physical planning aspects with a case study of the village of Sweimeh to answer the following questions:

-What is the urban impact of the DSDZ on local communities? - What is the socio-economic and physical impact caused by the touristic planning development of the DSDZ?

\section{MATERIALS AND METHODS}

The research methodology is based on a mixed-method approach, which includes both qualitative and quantitative strands. Descriptive statistics and content analysis were used to analyze the collected data. The research assumes that the DSDZ has a socio-economic impact on the tourism industry in Jordan and aims to explore how the DSDZ affects the emergence of new urban forms.

The quantitative data is based on previous studies and comprises data sets derived from satellite images, maps, and aerial photographs. The strategic master plan of the DS was used to extract data and get a more precise mapping and classification of the existing shoreline conditions and land-use patterns of the north shore. The qualitative analysis combines field observations, questionnaire surveys, and semi-structured interviews with 30 purposively selected participants (10 officials from the DSDZ, 10 officials from the local authorities, and 10 business investors in hotels and restaurants).

The structured questionnaire survey was based on a simple two-point dichotomous scale (Yes or No questions), which was deliberately simple to ensure that participants from the case study village of Sweimeh understand the questions and answers clearly. The sample of the questionnaire survey from the village was based on household units rather than individual respondents, considering each family as a single unit.

The suitable sample size for the field survey questionnaire was calculated using Raosoft Sample Size Calculator, with a 95\% Confidence Level ( $Z$ Score $=1.96)$, 5\% margin of error (0.05), and sample proportion of $50 \%(=0.5)$ :

$$
\text { sample size }=\frac{N *\left(\left(Z_{\frac{\alpha}{2}}\right)^{2} * p *(1-p) / M O E^{2}\right)}{\left(\left(\left(Z_{\frac{\alpha}{2}}\right)^{2} * p *(1-p) / M O E^{2}\right)+N-1\right)}
$$

Where

$\mathrm{Za} / 2$ is the critical value of the Normal distribution at a/2 (e.g. for a confidence level of $95 \%$, a is 0.05 , and the critical value is 1.96), MOE is the margin of error, $p$ is the sample proportion, and $\mathrm{N}$ is the population size.

According to official statistics, the population of Sweimeh is around 4448. The average household size is 5.5 people per house. Accordingly, there are approximately 4448/5.5 = 803 households in Sweimeh, thus the sample size for the needed questionnaire survey is:

$$
\text { sample size }=\frac{803 *\left((1.96)^{2} * 0.5 *(1-0.5) / 0.05^{2}\right)}{\left(\left((1.96)^{2} * 0.5 *(1-0.5) / 0.05^{2}\right)+803-1\right)}=261 \text { households }
$$

The researchers distributed questionnaires during field visits to randomly selected households. The data gathered from 270 questionnaires were translated by the researchers from Arabic into English, transcribed and coded. The questions of the questionnaire were categorized into two major themes: the first measured socio-economic impact of the DSDZ; and the second measured physical impact. The results are shown in Table 1.

\begin{tabular}{|c|c|c|}
\hline \multirow{2}{*}{ Survey Questions } & \multicolumn{2}{|c|}{ Percentage } \\
\hline & Yes & No \\
\hline \multicolumn{3}{|l|}{ Socio-economic } \\
\hline Do you think that jobs in the tourism sector are stable and permanent? & 11.3 & 88.7 \\
\hline Do you think that jobs in the tourism, business, public sectors are better than working in agriculture? & 88.9 & 11.1 \\
\hline Have you participated in discussions about your needs with the developers before the tourism development projects? & 10.3 & 89.7 \\
\hline Do tourism development projects increase options for shopping, entertainment, and restaurants? & 65.4 & 34.6 \\
\hline Do tourism development projects increase your income? & 70 & 30 \\
\hline Did the new residential projects increase the social inequality between the local residents and the new settlers? & 84 & 16 \\
\hline $\begin{array}{l}\text { Do you think that tourism development projects can generate negative cultural problems due to the cultural and moral } \\
\qquad \text { differences between tourists and the local communities? }\end{array}$ & 20 & 80 \\
\hline \multicolumn{3}{|l|}{ Physical } \\
\hline $\begin{array}{l}\text { Are the conditions of infrastructure (roads, sewage, and drainage) in Sweimeh after the development project better } \\
\text { than the conditions before? }\end{array}$ & 75.2 & 24.8 \\
\hline $\begin{array}{l}\text { Did the newly annexed parts of the Sweimeh municipal boundaries at the borders of the development zone affect your } \\
\text { living conditions? }\end{array}$ & 34.6 & 65.4 \\
\hline Are the service facilities such as showers, restrooms, and changing rooms enough on public beaches? & 5.9 & 94.1 \\
\hline Is there periodic cleaning for public beaches? & 20.0 & 80.0 \\
\hline
\end{tabular}

\section{Table 1. Questionnaire results}

Source: Authors 


\section{DISCUSSION AND RESULTS}

\section{Socio-economic impacts}

Eraqi (2007) reported both positive and negative socio-cultural and economic impacts of tourism development on local communities in neighboring Egypt, measuring the impact of tourism development on the standard of living of local Egyptian communities and their attitudes. The cultural, socio-economic, and climatic similarities between local communities in Egypt and agricultural communities in the DS Jordan Valley make these findings pertinent. Tsundoda and Mendilinger (2009) noted that tourism is a total social event, which may be beneficial to cultural life in communities. Locals at the DS are encouraged to share their culture with tourists in a celebratory and proud way. This cultural interaction helps in educating young locals to take pride in their origins. In contrast, tourism development projects can also generate negative impacts, causing cultural problems due to the differences between tourists and host communities (Ap 1992). These projects can damage local social and cultural values due to the possible increase of social problems associated with tourism development, such as crime, prostitution, and drugs, which affects local communities.

Mathieson and Wall (2006) argued that the negative social impact of tourism can be categorized into three groups: social change, tourism and health, tourism and language. The extent of such influences varies from local residents to owners of hotels and restaurants on the DS. 80\% of the resident participants emphasized that there is no direct social interaction between foreign tourists and themselves, since the latter stay in the fivestar gated hotel district. Interviews with investors in the tourism sector, such as hotel and restaurant owners, revealed that young, educated, and trained local people who worked for hotels and restaurants were culturally influenced by wealthy foreign tourists; in addition, this cultural interaction enhanced their language and communication proficiency.

The economic impact of tourism affects the production, distribution, and consumption of wealth in human societies (Ashley and Mitchell 2010). The host community is usually quite happy to see the influx of tourists into their living areas where many recreational activities are organized and planned to welcome people, who subsequently spend their money there, generating revenue for the community (Allen et al. 1988). According to Edgall (2006), the economic impact of tourism includes new commerce, job creation, new products, increased income, enhanced infrastructure, economic diversification, and economic integration of the local economy, as well as linkages between local services and products and the tourism sector (Gnanapala and Sandaruwani 2016).

Murray Simpson (2009) has listed a set of positive impacts of tourism on the local economy, including direct opportunities of employment in administration, guiding, tours and transport, construction, hospitality, management, accommodation, shopping, food and beverage outlets. He also added a number of impacts of tourism on the governmental level, such as indirect employment opportunities (including environmental management, entrepreneurs, and other supportive industries), support of the development of multisector or mono-sector non-profit community-based enterprises, provision of alternatives to changing or fading traditional industries, and increase in land value. According to the JFDZ Group (2016), the existing hotels of the DSDZ provide about 3,700 jobs. It is expected that the new developments will provide around 8,800 job opportunities upon the construction of the recreational and touristic facilities proposed in the Dead Sea Master Plan (DSMP). This more than doubles the current number of direct opportunities, aside from other indirect employment opportunities. There are significantly more male Jordanian workers in the DS tourism industry, which has been the case since 2004. Given the education and gender characteristics of the local community, people of the area can generally only fill low-grade service jobs (e.g., concierge, clerk, baggage porter, bellman, valet and so on), while managerial and leadership roles in the hospitality industry typically go to Jordanian locals with superior educational background from the major cities (Amman, Zarqa, and Irbid), or international employees appointed by multinational hotel chains (Fig. 3).

Conversely, tourism can generate negative economic impacts. For example, tourism is an unstable and highly unpredictable income source (Tosun 2001), influenced by political instability (Russel and Faulkrar 2004). Furthermore, a booming tourism industry places great pressure on local resources, such as food, land, transport, electricity and water supply, etc., limited in the host economy, increasing the demand and facilitating inflation of prices for local communities. 75\% of respondents agreed that uncontrolled commodity prices doubled or even tripled over the weekends and in the tourist seasons. Tourism creates jobs that are not sustainable (Munt 1994), do not require professional skills, and do not provide a sufficient salary to afford family expenses (Mathieson and Wall 2006; Page and Connell 2006). Questionnaire responses regarding job stability and income revealed that $88.7 \%$ of participants employed in the DSDZ did not feel job stability, and they were mainly working on short-term contracts without any health insurance or social security benefits.

Another negative aspect reported by participants was that most owners of stores and service facilities were reorienting their businesses towards serving tourists rather than locals, seeking increased profitability. Expensive tourist restaurants are generally beyond the spending reach of local people; for example, residents of Sweimeh village are visibly poor. According to the survey, only $6.0 \%$ of the respondents could afford to sit and eat in these restaurants. Page and Connell (2006) indicated that poor local communities may not benefit from tourism development, as their income may be accrued by tourist businesses and governments, without trickling down to local people. While the income from tourism is often syphoned away from local people, they are always subject to price increase due to tourism development, including land and property values, especially when there is a sustained demand for building tourism facilities. This creates inflationary effect on local economy with increasing land and property prices often making young people unable to afford to continue residing in their local communities, while local residents are forced to pay more for their homes and taxes (Mathieson and Wall 2006).

\section{Physical impacts}

Urban forms in the DSDZ nowadays undergo 


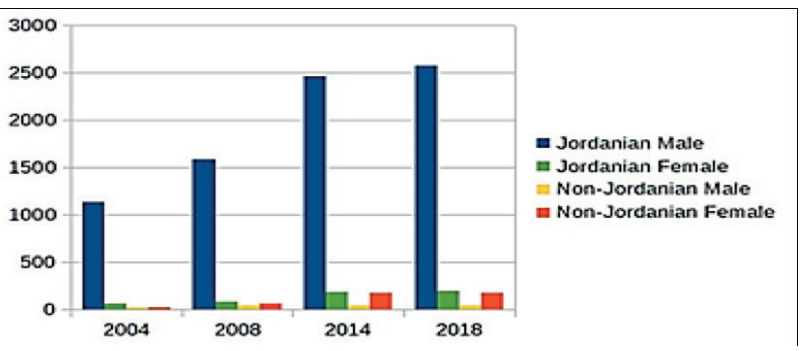

Fig. 3. Number of employees at the DS hotels according to gender and nationality

Source: JFDZ Group (2019)

immense changes in their character and land use, with expanding levels of tourist economic development in the region. Collected data in this research plays a significant role in exploring these changes, uncovering persistent and obvious patterns of land use and exhibiting perspectives for the landscape, while satellite images offer extensive advantages over verified maps, as explained in this section. The main focus is on the local level of urban analysis, with the case study area of Sweimeh, a small village about $74 \mathrm{~km}$ from Amman, located on the northeast shore of the DS within the DS Strategic Development Plan Zone (Fig. 2). The village makes an ideal case for the current study as it is the smallest and poorest settlement in the DS area and the closest urban settlement to the touristic development zone. Furthermore, there are few urban studies on the relationship between poor settlements and tourist development programs in Jordan.

According to Pivo (1992), two basic components of urban form are consistently debated. One component includes a variety of physical elements encompassing configurations of land use, urban design aspects, and transportation networks. The second component treats urban form as an ever-changing process. In general, the physical elements are in a constant state of change due to political, social, and economic forces. The interrelation between the two components in the DS area illustrates the complexity of its urban form. In this section, we focus on the individual village of Sweimeh as part of the new DS shoreline strategic master plan produced in 2011.

Sweimeh is part of the Balqa governorate. It is a poor rural settlement with inadequate basic services and infrastructure (Fig. 4). The modern urban history of Sweimeh dates back to the beginning of the twentieth century. It was originally considered a retreat for a group of clans (herders and farmers) who came from the southern Jordan Valley. It gradually became a permanent settlement of mud-brick houses and then concrete bricks from the early 1940s. Previously, the site was inhabited due to the abundance of water. The residents planted vegetables, as well as wheat and barley. Nevertheless, the recently mechanized agriculture operated by investors put an end to the traditional local agricultural production over the last two decades. The survey results indicated that $88.9 \%$ of the respondents believed that the economic future for younger generations was very much framed around urban context, with a clear demand for non-agricultural employment and income.

The DSDZ generates wage income for the local workers higher than the increase in the local cost of living in the old village. The local residents have experience in developing their small family businesses, including selling handicrafts, reed baskets and so on. Those who owned land close to the hotel district started with tourist stores selling souvenirs and traditional restaurant services along the main road. $65.4 \%$ of the survey respondents agreed that tourists increased options for shopping, entertainment, and restaurants. Their perception is that tourists contribute to sustaining local businesses, which are also used by local people. These small businesses increased their family income and encouraged the villagers to construct concrete homes or expand their existing households, own private cars, and have electrical and solar photovoltaic panel devices fitted to their homes for sustainable and cheap green energy (Fig. 4).

To control this urban growth, the Jordanian government approved the amendment of the development borders of the DS region from the northeastern side in 2016. It annexed parts of the municipal boundaries of Sweimeh to the development zone over an area of approximately 327 hectares (Fig. 5). The normal growth and the new expansion increased the area of the village from $0.15 \mathrm{~km}^{2}$ in 2004 to 4.40 $\mathrm{km}^{2}$. A limited number of the local people (34.6\%) were able to benefit from this emerging urban development (Rumonline 2018). There were considerable economic opportunities for the local people to profit from selling their agricultural land.

There has also been a notable increase in the population of Sweimeh since the 1950s as it grew from 267 people in 1953 to 2054 in 1994, while between 1994 and 2019 the population more than doubled reaching 4448 , as reported by the Jordanian Department of Statistics (DoS 2019). According to a study conducted by

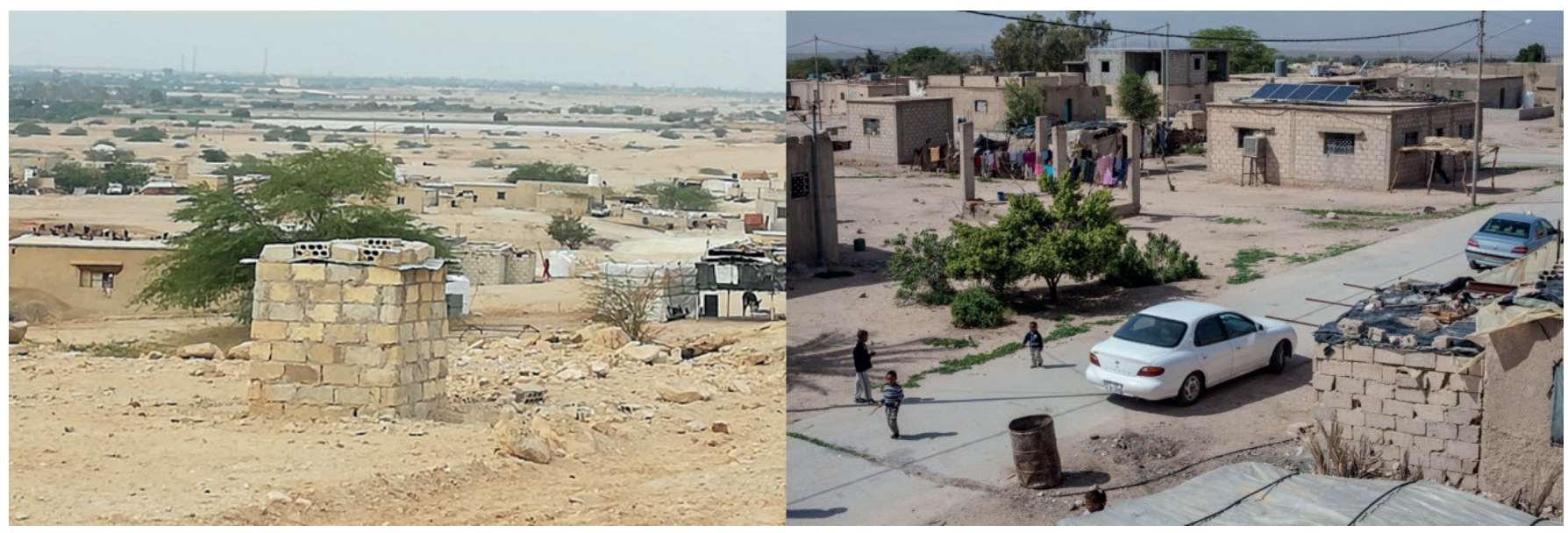

Fig. 4. Sweimeh village

Source: Aledwan (2019); Jordanzad (2019) 
the Directorate of Social Development, $40 \%$ of the town population are aged 1-15 years, $10 \%$ are in secondary school, 30\% have permanent jobs, and the rest are over 50 years old (Jordanzad 2019). This visible increase is attributable to normal population growth and the new emergent local economic business development, which attracted more young local people to stay close to their homes in Sweimeh (Table 2).

Over the past 15 years, the Jordanian government has focused on an equitable approach in terms of heritage preservation and tourism development. The main spatial planning strategy target was to maximize the benefits from tourism and provide improvements to local communities, so they held a design competition commissioned by the Jordan Development Zones Company (JDZC) to develop a master plan for the Dead Sea shoreline in 2011. The plan was produced by the well-known American planning and design firm Sasaki Associates, which won first place in the competition. Their spatial planning strategy revolved around the creation of 12 investment districts that address the conservation of natural and economic resources of each investment area. The detailed master plan covers 4,000 hectares and aims to provide the area with various investment opportunities for the upcoming 25 years. It aims to conserve the natural DS environment, embody the concept of sustainable development, and take all possible measures towards it (Sasaki Associates 2019).

In this study, we focused on two out of thirteen districts indicated in this plan: the Sweimeh urban district (Maroon) and the hotel district (Ochre). The color chart in the Dead Sea Master Plan Districts ranges from green to yellow, indicating the spatial distribution of the nine existing districts and the four new proposed ones (Fig. 6). Before the 1990s, the northeast coast was in the area now comprising the luxurious hotel district, the convention center, Amman shore, and the DS Porto districts, while the newly proposed four districts (The Panorama, North Zara, South Zara, and Mujeb Reserve) are set apart in a single zone on the east coast with fewer observable features.

According to the technical report of the DS Strategic Plan (Sasaki Associates 2019), there are four reasons behind not including the village of Sweimeh in the detailed development zone master plan. Firstly, the presence of Sweimeh in the upstream part of the northwest zone is hidden behind the hotel district, and separated by the DS high-speed highway (the maroon polygon); secondly, Sweimeh has few publicly controlled lands; thirdly, the village is located on flat land, and does not have a panoramic view towards the DS; and finally, the surrounding area of the village has low touristic development value. In return, the hotel zone is located on the seashore next to the sandy beach and has many access points from the service road of the DS highway. Additionally, the coastal lands are owned and controlled by the government and investment companies.

The Dead Sea Master Plan Districts (DSMPD) was only partially implemented, with a number of new housing projects being constructed by the individual private sector or foreign investors to the southeast of the old village, close to the local community's homes, on land that was once theirs. The result was the creation of planned residential areas of varying quality and standards. $84 \%$ of the respondents considered that the new housing projects had increased the division between the disadvantaged local residents and the privileged newcomers. The projects exacerbate social disparity due to the glaring contrast in levels of facilities

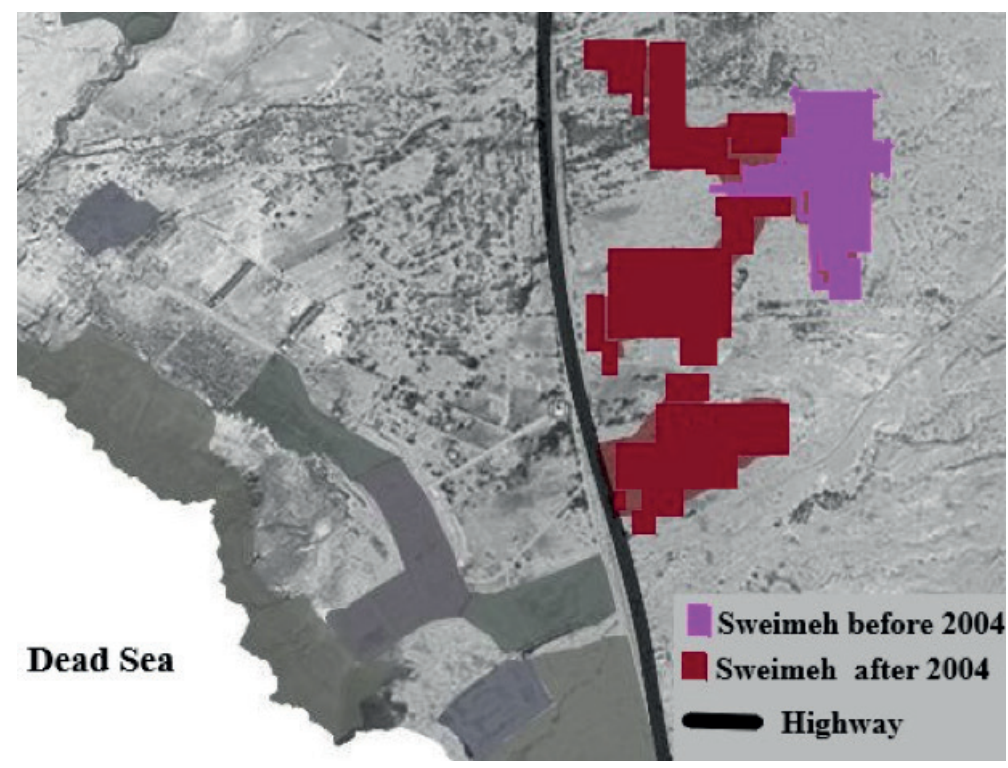

Fig. 5. Sweimeh urban growth, before and after 2004

Source: Alfuqaha et al. (2020)

Table 2. Sweimeh population growth

\begin{tabular}{|c|c|c|c|c|c|c|c|c|}
\hline Year & Population & $\begin{array}{c}\text { Household } \\
\text { no. }\end{array}$ & $\begin{array}{l}\text { Average } \\
\text { household }\end{array}$ & \multicolumn{2}{|c|}{ Growth percentage } & \multicolumn{2}{|c|}{$\begin{array}{c}\text { Annual percentage } \\
\text { growth }\end{array}$} & $\begin{array}{c}\text { Tourist jobs/ business } \\
\text { percentage }\end{array}$ \\
\hline 1953 & 267 & 49 & 5.4 & & \multirow{2}{*}{217} & & & 0 \\
\hline 1994 & 2054 & 270 & 7.6 & \multirow{2}{*}{769} & & \multirow{2}{*}{9.6} & & 10 \\
\hline 2019 & 4448 & 803 & 5.5 & & & & & 50 \\
\hline
\end{tabular}

Source: Authors 
between the two residential groups (Fig. 7). Conversely, one of the investors in these projects said that a large number of the new flats were not sold due to the poor conditions and attributions of the neighboring houses of local people in the old village of Sweimeh. The officials of the local authority of Sweimeh considered it to be their responsibility to provide services for the new housing projects, such as electricity, road construction, garbage collection and transportation, while there are no financial returns from these services since payments of these property tax bills are governed by a patchwork of state investment commissions and paid to the state, not the local governments which rely on property taxes to fund the services.

The DSDZ creates spatial inequality resulting from the high level of place-based development differences associated with urban characteristics, such as poor infrastructure and service provision. This spatial inequality is visible in the shoreline service provision, which is divided into luxurious private resort shorelines and unpleasantly overcrowded public beaches. The use of facilities and accommodation in the resorts and spa treatments are very expensive and unaffordable for the middle and lower class, while the free public beach is dirty and faces intense problems caused by coastal erosion, landslides, and sinkholes. It has no sandy beach and is frequently exposed to geological hazards (Fig. 7 \& Fig. 1) (Abu Khalil 2019). In addition, the public shore forms an environmental challenge to the local authority of Sweimeh, which suffers from financial problems and does not have enough garbage compressor trucks and sweepers to clean the shore.

In general, the DS shore is irregular along the coastline and has no beachfront due to the rough rocky terrain and narrow passes to beaches (Abou Karaki et al. 2019). The shore fails to function in terms of recreation or providing social and cultural activities (Abu Khalil 2017). In contrast, the DS resort beach, managed by the private sector, comprises various luxurious facilities in proximity to hotels. The beach has an aesthetically pleasing sea view, which plays an important role in the choices made by tourists, as well as in their willingness to pay higher hotel prices (Fig. 7).
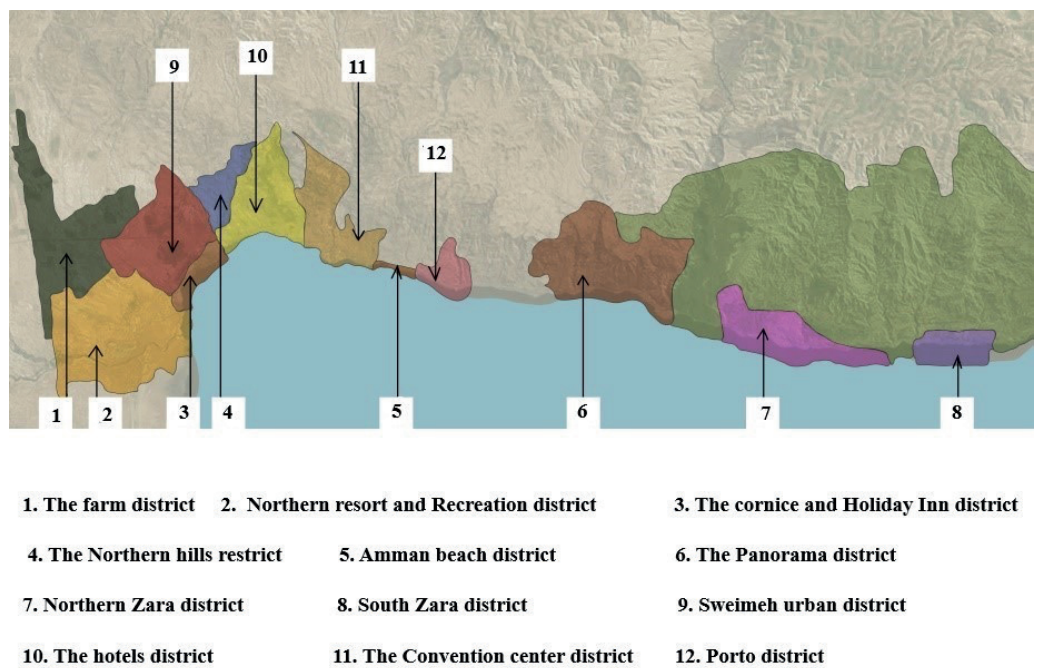

Fig. 6. Dead Sea Master Plan Districts

Source: Sasaki Associates (2019) illustrated by Alfuqaha et al. (2020)

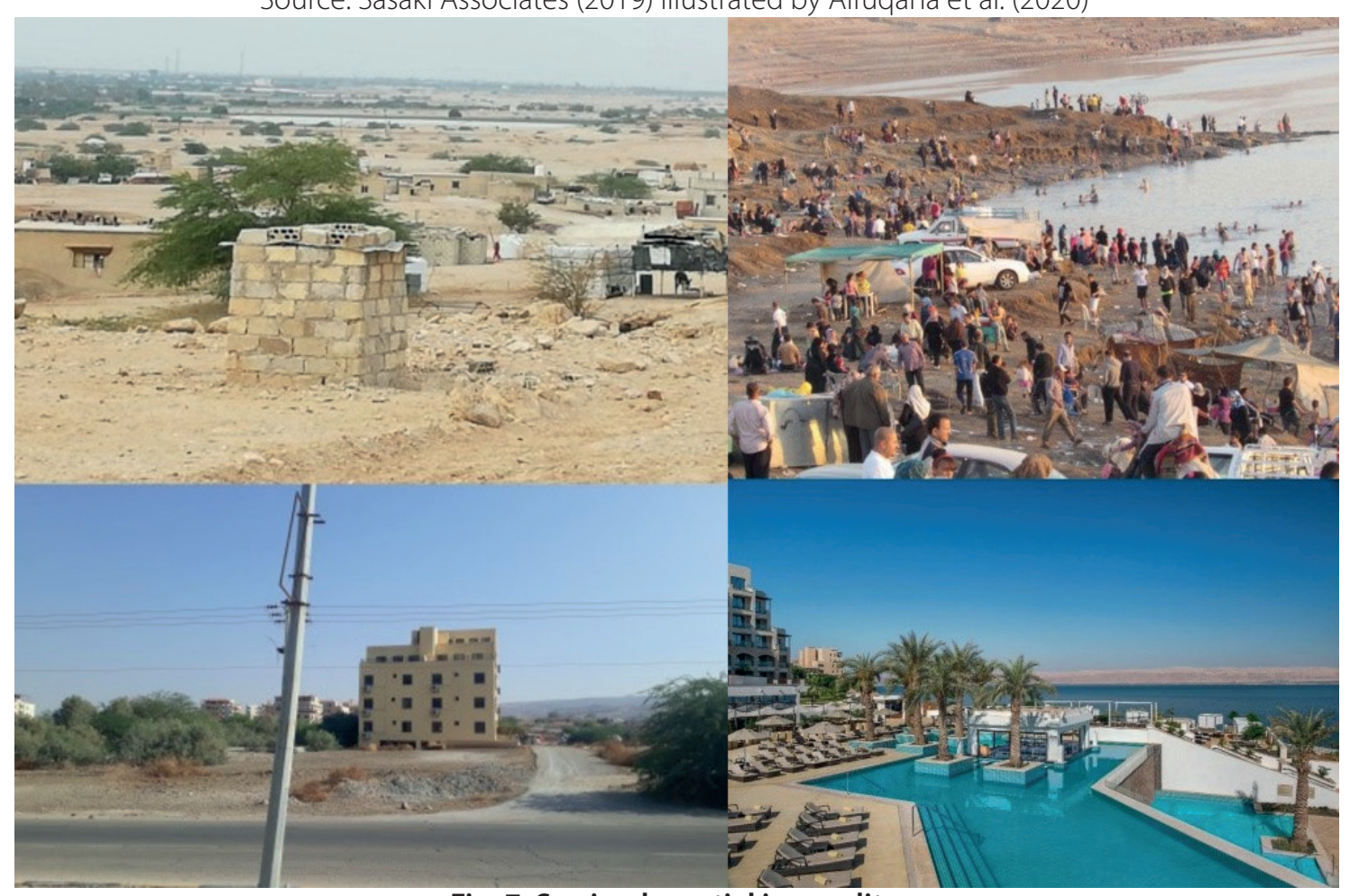

Fig. 7. Sweimeh spatial inequality

Source: Aledwan (2019) (top left); authors (2021) (down left); Abu Khalil (2019) (right) 
Finally, the Dead Sea Master Development Plan fails heavily in terms of land use planning. It was largely a technical process, executed out of the public domain, with expenditure skewed towards elite interests, displaying negligible concern for the socio-economic development of local people. New hotels and their associated resources, including the modified natural shoreline from which local people are now excluded, are clearly valued over new roads, schools, and hospitals for local citizens. Consequently, the inhabitants of Sweimeh exhibited a generally negative attitude towards the DSDZ because of the great attention paid to the development of the hotel district, while Sweimeh lacks basic services such as electricity and water.

\section{CONCLUSIONS}

The analysis demonstrates the general success of the DSDZ and its positive socio-economic impact on the national level, with negative social impact and unequal outcomes on the local level. Although tourism development zones inevitably generate some negative social and economic impacts, they can be extremely beneficial in helping to develop regional economic potential and in alleviating poverty. The researchers believe it is crucial to study the impact of the development zones through their social, environmental, spatial, and economic effects. It is important for planners to study and analyze worldwide case studies for a better understanding of the specificity of each project and the attributes that lead to either success or failure of such projects. Furthermore, local communities should be consulted and considered in every stage of planning and execution to avoid the kind of two-tier, discriminatory, and exclusive outcomes seen in Sweimeh.

This paper is important for two main reasons. Firstly, with urbanization and urban management receiving little attention in the DSDZ development agenda, it is necessary to understand why new forms of urban management are needed to address increasingly divisive urban inequality. Secondly, there is little interest of governments, investors, and other national agencies in the context of tourism development programs in the urban sector at the local level. At the academic level, the findings of this research help to establish an assessment tool for testing the socio-economic impacts of tourism development zones.

\section{REFERENCES}

Abu Khalil A. (2021). [Anti human investment: This is exactly what is happening in Sweimeh Village/ Dead Sea]. [online] [Zamanukum, Your Time]. (in Arabic with English summary) https://www.zamancom.com/?p=3420 [Accessed 2 May. 2021].

Abu Khalil A. (2017). The poor of the village of Sweimeh: a Tale of Two Cities. JO24.(in Arabic with English summary) http://www.jo24. net/post.php?id=225129 [Accessed 11 Nov. 2019].

Alfuqaha S., Jibrini H., Al Ayyoub A., \& Otoom O. (2020). The new Quarantine City in Dead Sea:The adaptive city of Dead Sea (unpublished report). German Jordanian University.

Aledwaan H. (2019). Sweimeh: Village without drinkable water for 5 months]. [online] [Alghad, Tomorrow].(in Arabic with English summary)https://alghad.com/ [Accessed 6 Oct.2019].

Allen L.R., Long P.T., Perdue R.R. \& Kieselbach S. (1988). The impact of tourism development on residents' perceptions of community life. Journal of Travel Research, 27(1), 16-21, DOI: 10.1177/004728758802700104.

Ap J. (1992). Residents' perceptions on tourism impacts. Annals of Tourism Research, 19(4), 665-690, DOI: 10.1016/0160-7383(92)90060-3. Ashley C., \& Mitchell J. (2010). Tourism and poverty reduction Pathways to prosperity. Overseas Development Institute. ISBN 9781844078899.

Tselem B. (2011). Dispossession and exploitation: Israel's policy in the Jordan Valley and Northern Dead Sea. htt://pswww.btselem.org/ publications/summaries/dispossession-and-exploitation-israels-policy-jordan-valley-northern-dead-sea. [Accessed 12 Jan. 2020].

Becker N. \& Katz D. (2006). Economic valuation of resuscitating the Dead Sea. Water Policy, 8(4), 351-370, DOI: 10.2166/wp.2006.050.

Department of statics and population. http://dosweb.dos.gov.jo/ar/population/[Accessed 20Apr. 2020].

Edgall D. (2006). Managing sustainable tourism: A legacy for the future. Psychology Press, 3rd edition, ISBN 9780367331382.

El-Naser H. (2020). The deal of the century and its hidden secrets. Jordan Times.

https://www.jordantimes.com/opinion/hazim-el-naser/\%E2\%80\%98-deal-century\%E2\%80\%99-and-its-hidden-secrets [Accessed 27 Feb. 2020]

Eraqi M.I. (2007). Local communities' attitudes towards impacts of tourism development in Egypt. Tourism Analysis, 12(3), 191-200, DOI: $10.3727 / 108354207781626848$.

Erdmann A., Pitigala S., \& Ziadeh A. (2016). Market assessment and demand forecast for the Jordan Dead Sea Development Zone: Published report to the Government of Jordan. USAID. https://jordankmportal.com/resources/market-assessment-and-demand-forecastfor-the-jordan-dead-sea-development-zone-2009 [Accessed 30Jan. 2019].

Friends of the Earth Middle East (1998). One basin, one strategy: Final report of the Symposium on Promoting an Integrated Sustainable Regional DevelopmentPlanfor theDeadSeaBasin.Jerusalem.http://www.globalnature.org/bausteine.net/f/5653/FinalProceedings[Accessed 12Jan. 2019].

Gnanapala A., \& Sandaruwani J. (2016). Socio-economic impacts of tourism development and their implications on local communities. International Journal of Economics and Business Administration, 2(5), 59-67 https://www.researchgate.net/publication/345901260_Socioeconomic_Impacts_of_Tourism_Development_and_Their_Implications_on_Local_Communities[Accessed 20 Feb. 2019].

JFDZ Group (2017). Development Zones annual report. JFDZ Group. https://www.jfdz.jo/jfz/DocumentsShowAr/5 [Accessed 15 Dec. 2019].

Jordan Investment Commission. (2014). Investment Law No.30 for the year 2014. https://www.jiec.com/uploaded/pdf/invest_law_e. pdf [Accessed 10 Dec. 2019].

Jordanzad (2019). Sweimeh: Misery and deprivation]. [online] (in Arabic with English summary)http://www.jordanzad.com/print. php?id=33658 [Accessed 20 Oct. 2019].

Google.(2021). https://www.google.com/search?q=jordan+israel+palestine+map\&oq=jordan+israel+palestine+map\&aqs=chrome..6 9i57j0i22i30.24525j0j7\&sourceid=chrome\&ie=UTF-8 [Accessed 10 Apr. 2021] 
Mathieson A., \& Wall G. (2006). Tourism:Economic, physical and social impacts. Longman,harlow. ISBN 058230061.

Munt I. (1994). The «Other» Postmodern Tourism: Culture, Travel and the New Middle Class. Theory, Culture and Society, 11, 101-123,

DOI: $10.1177 / 026327694011003005$.

Page S., \& Connell J. (2006). Tourism: A modern synthesis. Thomson. 5th edition, ISBN 9780367437367.

Pivo G., Abbott N., \& Perkins K. (1992). Local government planning tools. Growth Management Planning and Research Clearinghouse, Department of Urban Planning and Design. University of Washington, Seattle.

Rumonline (2018). [Sweimeh: The daily struggle of services shortage (water and electricity)] [online] (in Arabic with English summary) http://www.rumonline.net/index.php?page=article\&id=360172 [Accessed 9 Feb. 2019].

Russel R., \& Faulkrar B. (2001). Entrepreneurship, chaos and the tourism area lifecycle. Annals of Tourism Research, 31(3), 556-579, DOI:10.1016/J.ANNALS.2004.01.008.

Sasaki Associates (2019). Dead Sea Development Zone Detailed Master Plan. Sasaki Associates.https://www.sasaki.com/projects/deadsea-development-zone-detailed-master-plan/[Accessed 20 May. 2019].

Simpson M. (2009). An integrated approach to assess the impacts of tourism on community development and sustainable livelihoods. Community Development Journal, 442), 186-208, DOI:10.1093/CDJ/BSM048.

TeVelde D.W. (2001) Policies towards foreign direct investment in developing countries: Emerging best-practices and outstanding issues. Overseas Development Institute. https://cdn.odi.org/media/documents/5543.pdf [Accessed 11Feb. 2019].

Tosun C. (2001).Challenges of sustainable tourism development in the developing world: The case of Turkey. Tourism Management, 22(3), 289-303, DOI: 10.1016/S0261-5177(00)00060-1 [Accessed 10 March. 2019].

Treaty of Peace (1994). Treaty of Peace between the State of Israel and the Hashemite Kingdom of Jordan, 1994, 2042, 1-35325. https:// peacemaker.un.org/sites/peacemaker.un.org/files/IL\%20JO_941026_PeaceTreatylsraelJordan.pdf [Accessed 5 May. 2019].

Tsundoda T., \& Mendlinger S. (2009). Economic and social impact of tourism on a small town: Peterborough, New Hampshire. Journal of Service Science \&Management, 2, 61-70, https://file.scirp.org/pdf/JSSM20090200001_17893549.pdf [Accessed 12 Feb. 2019].

USAID (2016). Jordan Competitiveness Program fact sheet. USAID.

https://www.usaid.gov/jordan/fact-sheets/usaid-jordan-competitiveness-program [Accessed 10May. 2019].

Wendt J.A. (2016). Tourism development challenges on the Dead Sea shore. Limnological Review, 16(2), 105-112,

DOI 10.1515/limre-2016-0011. 